\title{
Jurist-Diction
}

Volume 3 No. 1, Januari 2020

\section{Implementasi Kebijakan Eco-Investment Pada Sebagai Perwujudan Pelaksanaan Pembangunan Berkelanjutan Berbasis Teknologi dan Kesejahteraan}

\author{
Yudi Yasmin Wijaya dan Shofi Munawwir Effendi \\ yudiyw123@gmail.com \\ Universitas Jember
}

\begin{abstract}
How to cite:
Yudi Yasmin Wijaya dan Shofi Munawwir Effendi, 'Implementasi Kebijakan Eco-Investment Pada Sebagai Perwujudan Pelaksanaan Pembangunan Berkelanjutan Berbasis Teknologi dan Kesejahteraan' (2020) Vol. 3 No. 1 Jurist-Diction.
\end{abstract}

Histori artikel:

Submit 6 Desember 2019; Diterima 12 Desember 2019; Diterbitkan 1 Januari 2020.

\section{DOI:}

10.20473/jd.v3i1.17641

\begin{abstract}
Abstrak
Investasi merupakan suatu kegiatan yang tidak dapat dilepaskan dari tujuan atas kesejahteraan. Konsep akan kesejahteraan pada kegiatan ini bertumpu pada kegiatan yang berbasis profit. Namun, perlu diketahui bahwa profit merupakan suatu tumpuan yang penting namun bukan yang satu-satunya. Konsep akan kesejahteraan memiliki banyak kriteria lain yang tidak dapat diabaikan begitu saja, salah satunya adalah pemenuhan terhadap Hak Asasi Manusia (HAM). Pemenuhan terhadap HAM merupakan hal yang sangat penting untuk diwujudkan sebagai salah satu kriteria kesejahteraan suatu negara. Pemenuhan atas keadaan lingkungan yang baik bagi masyarakat merupakan suatu perwujudan yang tidak dapat dihindarkan, dimana kemudian pemenuhan tersebut memerlukan suatu langkah yang efektif. Munculnya berbagai pemikiran dan innovasi menciptakan suatu gagasan yang berguna untuk merealisasi suatu keadaan seimbang yang menguntungkan dan sekaligus berkelanjutan. Keadaan ini direalisasikan dengan suatu kegiatan yang disebut dengan ecoinvestment atau investasi berbasis lingkungan. Perwujudan aktivitas ini dapat dilakukan dengan mewujudkan sistem kebijakan yang terintegrasi pada suatu negara khususnya daerah kota sebagai pemegang hak otonomi. Sebagai suatu kegiatan dengan tujuan yang besar maka unsur atas dasar hukum diperlukan sebagai pondasi kebijakan yang bersifat normatif. Penerapan atas eco-investment serta aturan perundang-undangan yang mengaturnya sangat diperlukan bagi Negara Indonesia. Sebagai negara yang bertujuan untuk memajukan teknologi atas investasi sekaligus pembangunan berkelanjutan yang efektif, maka kegiatan ini dapat menjadi salah satu solusi terbaik atas perwujudan kesejahteraan dan sebagai salah satu bentuk pemenuhan HAM.
\end{abstract}

Kata Kunci: Investasi; Hak Asasi Manusia (HAM); Lingkungan; Eco-investment; Kesejahteraan.

\section{Pendahuluan}

Kejahteraan merupakan suatu konsep dasar yang sering menjadi bahan tinjauan oleh para ahli ekonomi, filsafat, dan politik. ${ }^{1}$ Keadaan ini menjelaskan

${ }^{1}$ Alan Hamlin, 'The Idea of Welfare and the Welfare State' (2008) 8 Public Finance and Management 108. 
bahwa pengertian mengenai kesejahteraan dapat berbeda-beda sesuai dengan kajian yang mendasarinya. Namun, perbedaan yang terjadi tidak menghilangkan esensi sebenarnya dari kesejahteraan yang merupakan keadaan yang baik, diharapkan, dan dapat diterima tanpa pengecualian; dan berakar pada hak, kebutuhan, kesetaraan, dan keadilan. ${ }^{2}$ Dalam konsep politik, pemikiran mengenai kesejahteraan merupakan hal yang tidak dapat dihindarkan. Sifat tersebut disebabkan karena konsep akan kesejahteraan merupakan suatu buah pemikiran, dan merupakan suatu dasar terbentuknya suatu negara sebagai organisasi kekuasaan. ${ }^{3}$ Di lain pihak, dalam konsep ekonomi kesejahteraan juga merupakan suatu tujuan, namun memiliki basis pada keseimbangan nilai kemanfaatan antara individu yang dapat diterima oleh pihak yang mampu maupun tidak dalam perekonomian. ${ }^{4}$ Keberadaan kesejahteraan sebagai tujuan negara dalam memenuhi keseimbangan perekonomian, menciptakan sifat yang begitu penting dalam perwujudannya demi menciptakan keadaan yang baik dan dapat diterima oleh seluruh pihak.

Dengan adanya pandangan bahwa kesejahteraan merupakan suatu dasar terbentuknya suatu negara, maka secara harfiah Indonesia memiliki kewajiban dalam mewujudkan kesejahteraan itu. Keinginan untuk mewujudkan tujuan akan kesejahteraan tertera pada Pembukaan Undang-Undang Dasar Negara Republik Indonesia Tahun $1945^{5}$ yang menyatakan bahwa, sebagian tujuan dari Negara Indonesia adalah memajukan kesejahteraan umum berdasarkan keadilan sosial. ${ }^{6}$ Pernyataan tersebut menjelaskan bahwa perwujudan kesejahteraan juga merupakan tujuan dari Negara Republik Indonesia dengan dasar atas keadilan masyarakat. Sebagai suatu cita-cita maka pembukaan ini menjadi dasar yang

\footnotetext{
2 Lihat Norman P Barry, 'The Philosophy of The Welfare State' (1990) 4 Critical Review: A Journal of Politics and Society 547.

3 Buah pemikiran ini membentuk negara dengan memberikannya suatu tujuan sebagai wadah perwujudan atas kesejahteraan itu sendiri. Lihat Soehino, Ilmu Negara (Liberty Yogyakarta 2015) [146-147].

4 Pandangan ini tercipta dari atas pandangan negatif bahwa penekanan pada kemampuan perekonomian antara pihak yang mampu dan kurang mampu melangkahi kepatutan. Lihat LG Melville, 'Economic Welfare' (1939) 49 The Economic Journal 552.

5 Selanjutnya disingkat "UUD NRI 1945".

6 UUD NRI 1945 [Pembukaan (Preambule) Alinea Keempat].
} 
kuat dan sekaligus pembentuk dari dasar hukum tertinggi negara yaitu UUD NRI 1945. ${ }^{7}$ Konsep mengenai kesejahteraan dalam dasar hukum tertinggi negara berada pada bagian ke empat belas yang berupa kesatuan antara peraturan terkait ekonomi serta kesejahteraan. ${ }^{8}$ Perpaduan antara kedua hal tersebut menjadi dasar bahwa kesejahteraan sosial dan perekonomian negara memiliki hubungan yang erat. Hubungan tersebut digambarkan oleh: penyusunan sektor perekonomian yang berasas kekeluargaan; penguasaan sektor produksi yang essensial bagi negara, sumber daya alam yang vital bagi masyarakat; dan penyelenggaraan demokrasi ekonomi dengan prinsip komunal, efisiensi yang adil, berkelanjutan, berbasis lingkungan, kemandirian, serta menjaga keseimbangan kemajuan dan kesatuan ekonomi negara. ${ }^{9}$

Dasar hukum yang berkaitan dengan konsep kesejahteraan terutama pada lingkup perekonomian pada dasar hukum tertinggi dapat menjadi dasar yang matang pada setiap kegiatan yang berkaitan dengan ekonomi. Salah satu sektor kegiatan dalam bidang perekonomian negara adalah investasi. Penekanan pada kegiatan ini dikarenakan oleh sifatnya yang harus serta niscaya untuk dilakukan, karena kegiatan ini merupakan mesin penggerak kemajuan ekonomi agar berkembang selaras dengan kebutuhan masyarakat..$^{10}$ Pernyataan atas investasi tersebut menjelaskan bahwa investasi merupakan suatu aksi yang wajib untuk dilakukan, dan yang menyebabkan pentingnya kegiatan tersebut adalah potensinya dalam menggerakkan perekonomian negara. Konteks dari investasi yang berasal dari pengertian atas investasi itu sendiri yang berupa suatu kegiatan menaruh sejumlah uang pada suatu proyek finansial, pembagian, atau properti dengan tujuan

\footnotetext{
7 Pernyataan ini tertera pada bagian jenis dan hierarki Peraturan Perundang-Undangan. Lihat Undang-Undang Nomor 12 Tahun 2011 Tentang Pembentukan Peraturan Perundang-Undangan (Lembaran Negara Republik Indonesia Tahun 2011 Nomor 82, Tambahan Lembaran Negara Republik Indonesia Nomor 5234) [Pasal 7, Ayat 1].

8 Pernyataan ini diambil dari Bab XIV yang merupakan gabungan judul dari "Perekonomian Nasional" dan "Kesejahteraan Sosial. Lihat UUD NRI 1945, [Bab XIV].

9 ibid [Pasal 33, Ayat 1-4].

${ }^{10}$ Pandangan yang berasal dari Pidato Pengukuhan Guru Besar Fakultas Hukum pada Bidang Investasi, Universitas Airlangga. Lihat Muchammad Zaidun, 'Paradigma Baru Kebijakan Hukum Investasi Indonesia Suatu Tantangan Dan Harapan’ (2008) 2.
} 
untuk mendapatkan profit. ${ }^{11}$ Pengertian tersebut menggambarkan bahwa investasi merupakan kegiatan menanam yang diharapkan akan menghasilkan keuntungan, dimana kemudian hal ini dapat memberikan tafsir yang sangat beragam. Penafsiran yang beragam akan keuntungan tidak jarang menimbulkan masalah dalam iklim investasi terutama pada lingkup investasi internasional.

Perlu diketahui bahwa pada dasarnya kegiatan investasi yang dilakukan oleh pihak asing di negara berkembang ${ }^{12}$ tidak hanya berbasis pada pembangunan jangka panjang yang berkaitan dengan arus modal, namun juga penyaluran sarana seperti teknologi, cara kerja, dan keuntungan, tanpa adanya kontribusi pada beban hutang negara. ${ }^{13}$ Investasi asing bertujuan untuk pembangunan jangka panjang yang ditunjang dengan disertai pemberian pengetahuan tanpa membebani negara yang dituju. Namun, faktanya ketertarikan akan konsep investasi asing ini malah mencerminkan yang sebaliknya atas isu lingkungan. ${ }^{14}$ Cerminan ini menimbulkan keadaan rendahnya perhatian terhadap lingkungan menjadi permasalahan yang terjadi pada negara-negara berkembang khususnya Indonesia sebagai salah satunya. Keadaan ini terbukti dengan keadaan Indonesia yang mengalami permasalahan mengenai eksploitasi sumber daya alam dan polusi yang terjadi beberapa tahun terakhir. ${ }^{15}$ Penggunaan teknologi yang tidak berkelanjutan menjadi isu yang sering dijumpai dalam sistem pengelolaannya. Menurut data dari $\mathrm{APEC}^{16}$ pada tahun 2012, keadaan yang terjadi di Indonesia disebabkan oleh adanya sikap pemerintah Indonesia yang tidak berani mengambil langkah akan adopsi teknologi berkelanjutan

\footnotetext{
${ }^{11}$ Pernyataan dari sumber bertumpu pada Concise Oxford English Dictionary, 11th ed. Lihat Michael Hwang and Jennifer Fong Lee Cheng, 'Definition of "Investment"” A Voice from the Eye of the Storm' (2011) 1 Asian Journal of International Law 100.

${ }_{12}$ Istilah ini biasa disebut dengan FDI atau Foreign Direct Investment.

13 Mohamed F Sweify, 'Investment-Environment Disputes: Challenges and Proposals' (2016) 14 DePaul Business \& Commercial Law Journal 133.

${ }_{14}$ Padahal sebenarnya faktor lingkungan dapat mempengaruhi iklim perdamaian dan keamanan dunia. Lihat ibid.

${ }^{15}$ Andewi Rokhmawati and Ardi Gunardi, 'Is Going Green Good for Profit? Empirical Evidence from Listed Manufacturing Firms in Indonesia' (2017) 7 International Journal of Energy Economics and Policy 181.

${ }_{16}$ Merupakan singkatan dari Asia-Pacific Economic Cooperation yang merupakan forum internasional yang teridiri atas 21 negara yang mempromosikan sistem perdagangan bebas.
} 
karena biaya investasi yang terlalu tinggi. ${ }^{17}$ Kondisi perekonomian yang ada pada Indonesia sebagai negara berkembang tidak dapat memungkiri ketakutan akan pembiayaan yang terlalu tinggi hanya untuk satu sektor saja. Namun, alasan dari pemerintah ini secara tidak langsung bertentangan dengan cita-cita negara yang di tuangkan dalam Pasal 33 UUD NRI 1945 yang mengutamakan pembangunan berkelanjutan berbasis lingkungan.

Sesuai dengan ketentuan dalam UUD NRI 1945 bahwa pemenuhan terhadap lingkungan yang baik merupakan suatu bentuk pemenuhan HAM sebagai hak dasar setiap manusia. ${ }^{18}$ Sebagai suatu kegiatan yang berbasis ekonomi, investasi secara tidak langsung wajib memiliki tujuan perwujudan kesejahteraan sesuai dengan citacita bangsa Indonesia. Salah satu dari cita-cita tersebut adalah melakukan usaha pembangunan berkelanjutan, yang pada dasarnya negara-negara berkembang, salah satunya Indonesia, masih belum berani mengambil langkah yang berarti. Dillema dalam mewujudkan profit dan sekaligus menanggulangi masalah akan lingkungan inilah yang akhirnya menciptakan konsep tentang Eco-investment yang merupakan istilah yang berkaitan dengan praktek dari perusahaan yang memiliki memiliki tujuan untuk mengurangi dampak langsung maupun tidak langsung yang berkaitan dengan lingkungan. ${ }^{19}$ Praktek yang ada merupakan bagian dari sebuah proses yang terorganisir, sekaligus dampak yang berkaitan dengan keseluruhan rantai dari produksi dan jasa. Jadi eco-investment adalah suatu gerakan investasi hijau ${ }^{20}$ yang berorientasi pada keberlanjutan dari rantai produksi yang mengutamakan faktor lingkungan.

Sesuai dengan prinsip dari Green Economy Initiatives dari Perserikatan Bangsa-Bangsa (PBB) pada tahun 2008, konsep eco-investment yang dilakukan berfokus pada keuntungan yang diberikan secara sosial dan ekologi yang dapat berupa peningkatan kualitas kehidupan manusia, dan kesetaraan yang pada saat

\footnotetext{
${ }^{17}$ Rokhmawati and Gunardi (n 15).

18 Tertera pada hak atas lingkungan hidup yang baik dan sehat. Lihat UUD NRI 1945 [Pasal 28H].

19 Renato J Orsato, Sustainability Strategies: When Does It Pay to Be Green? (Palgrave Mancmillan 2009).

${ }^{20}$ Eco-investment merupakan bagian dari gerakan green investment.
} 
bersamaan mengurangi resiko lingkungan, dan kelangkaan lingkungan. ${ }^{21}$ Pernyataan tersebut sekaligus menjelaskan bahwa eco-investment merupakan suatu gerakan baru atas investasi yang memiliki karakteristik tidak berdasarkan profit finansial namun profit penjagaan kualitas keadaan sosial serta lingkungan yang baik. Konsep tentang keuntungan berbasis peningkatan keuanagan yang diubah menjadi konsep pengurangan emisi karbon, peningkatan efisiensi sumber daya, dan sosialitas yang inklusif ${ }^{22}$ menjadikan gerakan eco-investment menjadi suatu gebrakan yang innovatif untuk dilakukan sebagai HAM terhadap lingkungan yang baik.

Hubungan antara HAM dan lingkungan merupakan hubungan yang pada dasarnya memiliki kaitan yang kuat. Pernyataan tersebut didasarkan pada Pasal 1 dari Deklarasi Stockholm atas Lingkungan Manusia, yang menyatakan bahwa perlindungan terhadap lingkungan adalah sangat penting bagi kesejahteraan manusia dan merupakan salah satu bentuk penikamatan atas dasar HAM, yang berkaitan dengan hak atas hidup itu sendiri. ${ }^{23}$ Berkaitan dengan masalah perekonomian yaitu investasi, maka pemenuhan HAM wajib untuk dilakukan. Kewajiban ini berkaitan atas dasar pemenuhan HAM dari investasi yang yang menjalankan tanggungjawab sosial komprehensif dan lebih dari sekedar menjalankan kebijakan perusahaan atau industri, yang dapat mempromosikan HAM secara lebih kuat. ${ }^{24}$ Jika dikaitakan dengan pengertian dari eco-investment, maka pandangan terhadap keuntungan memerlukan pandangan yang lebih luas dari sekedar keuntungan finansial.

\footnotetext{
${ }^{21}$ United Nations Environment Programme, 'Delivering the Green Economy through Financial Policy' (2014).

${ }^{22}$ Fortune Ganda, Collins C Ngwakwe and Cosmas M Ambe, 'Profitability as a Factor That Spurs Corporate Green Investment Practices in Johannesburg Stock Exchange (Jse) Listed Firms' (2015) 13 Managing Global Transitions 233.

${ }^{23}$ Berkaitan dengan bagian Pembukaan (Preambule) dari Aarhus Convention on Access to Information, Public Participation in Decision-making and Access to Justice in Environmental Matters. Lihat Alan Boyle, 'Human Rights and the Environment: Where Next?' (2012) 23 The European Journal of International Law 622.

${ }^{24}$ John Gerard Ruggie, 'Business and Human Rights: The Evolving International Agenda' (2011) 101 The American Journal of International Law 837.the most visible embodiment of globalization. This paper reviews two recent chapters in this endeavor, focused specifically on human rights: the \"Draft Norms on the Responsibilities of Transnational Corporations and Other Business Enterprises with Regard to Human Rights, $\$ " adopted by the United Nations Sub-Commission on the Promotion and Protection of Human Rights but not by its parent body, the UN Human Rights Commission (since replaced by the Human Rights Council.
} 
Maka dari itu, kewajiban yang ada pada kegiatan investasi memerlukan proyek yang menerapkan kebijakan HAM secara penuh yang ternyata memang sebagian besar berkaitan dengan isu akan lingkungan. ${ }^{25}$ Keadaan mengenai iklim investasi yang berbasis lingkungan serta kaitannya dengan pemuhan hak asasi manusia menunjukkan bahwa dunia telah bergerak mewujudkan suatu kesejahteraan. Namun dalam mewujudkan tujuan tersebut, peran dari politik memerlukan perhatian yang khusus terutama pada kebijakan hukum. Dalam program Environmental, Social, and Corporate Governance, ${ }^{26}$ regulasi merupakan salah satu dari lima faktor yang berpengaruh pada kebijakan lingkungan yang baik. ${ }^{27}$ Pengaruh tersebut disebabkan oleh karena peraturan diperlukan untuk mempersiapkan penyesuaian kebutuhan akan lingkungan yang ada pada masyarakat. Dengan adanya dasar hukum yang kuat dan terstruktur, penerapan dari eco-investment sebagai investasi yang bermanfaat sebenarnya dapat dijamin pelaksanaannya secara baik. Keadaan ini sekaligus dapat berpotensi memberikan manfaat bagi masyarakat secara berkelanjutan.

Berdasarkan dengan uraian yang telah disampaikan, maka artikel ini akan membahas implementasi kebijakan regulasi eco-investment di Indonesia sebagai perwujudan pembangunan berkelanjutan. Pembahasan tersebut sekaligus dilakukan untuk mencari solusi penerapan yang tepat agar tujuan dari penjagaan lingkungan, dan pemenuhan HAM sebagai wujud dari kesejahteraan. Artikel ini akan menelaah konsep mengenai hukum investasi berbasis lingkungan secara interdisipliner. Penelaahan konsep dilakukan melalui penelitian berbasis doktrinal

${ }^{25}$ Pernyataan ini merupakan respon yang berdasarkan atas Laporan SRSG dalam Human Rights Impact and Assesment: Resolving Key Methodological Questions, UN Doc. A/HRC/4/74. Lihat Ibid.the most visible embodiment of globalization. This paper reviews two recent chapters in this endeavor, focused specifically on human rights: the I"Draft Norms on the Responsibilities of Transnational Corporations and Other Business Enterprises with Regard to Human Rights, ।" adopted by the United Nations Sub-Commission on the Promotion and Protection of Human Rights but not by its parent body, the UN Human Rights Commission (since replaced by the Human Rights Council.

${ }^{26}$ Environmental, Social, and Corporate Governance atau ESG merupakan program pemajuan lingkungan yang salah satunya meng-cover tentang investasi berbasis lingkungan atau green investment.

${ }^{27}$ Lihat Satyajit Bose and Amy Springstell, 'The Value and Current Limitations of ESG Data for the Security Selector' (2017) 8 Journal of Environmental Investing 66. 
dengan menelaah secara teliti berbagai pemikiran tentang aturan ${ }^{28}$ investasi dan pembangunan berkelanjutan. Pendekatan secara perundangan, dan konseptual menjadi titik tumpu penelitian ini yang berbasis kualitatif dengan pengumpulan data secara kepustakaan. ${ }^{29}$ Artikel ini akan membahas dua topik permasalahan: pertama, bagaimana keadaan legislasi eco-investment di Indonesia sebagai bentuk pemenuhan HAM atas lingkungan. Pada topic permasalahan ini akan dibahas mengenai keadaan investasi khususnya eco-investment, serta penerapan aturannya di Indonesia beberapa waktu terakhir dalam konteks pemenuhan HAM atas lingkungan. Kedua, bagaimana komparasi legislasi eco-investment dalam konteks pemenuhan HAM atas lingkungan pada daerah perkotaan di Indonesia. Topik permasalahan yang kedua ini akan membahas tentang langkah yang sebaiknya diambil oleh negara dalam kegiatan eco-investment sebagai pemenuhan HAM. Pada topik yang kedua, akan digunakan pembandingan kebijakan eco-investment dan sistem perkotaan di Indonesia dalam konteks pemenuhan HAM. Pembahasan terkait kedua permasalahan tersebut tentunya memiliki tujuan untuk memperluas pandangan akan investasi sebagai penggerak roda ekonomi atas pembangunan berkelanjutan berbasis lingkungan dalam konteks hukum.

\section{Investasi di Indonesia: Keadaan Regulasi Berbasis Pemenuhan HAM Atas Lingkungan}

Dasar regulasi atas pemenuhan atas kebutuhan lingkungan yang baik tertera pada UUD NRI sebagai dasar hukum tertinggi negara. ${ }^{30}$ Adanya dasar hukum tersebut membuktikan bahwa Indonesia sebagai sebuah negara telah memiliki wadah untuk mewujudkan tujuan pemenuhan HAM atas keadaan lingkungan

\footnotetext{
${ }^{28}$ Penelitian hukum secara doktrinal dilakukan dengan mengumpulkan pemikiran-pemikiran hukum dari berbagai sumber hukum. Lihat Terry Hutchinson, 'Doctrinal Research: Researching the Jury' in Dawn Watkins and Mandy Burton (eds), Research Methods in Law (Routledge 2013).

${ }_{29}$ Telaah yang dilakukan dengan memilih beberapa aspek penelitian yang telah disebutkan sebelumnya. Lihat Dyah Ochtorina Susanti and A'an Efendi, Penelitian Hukum (Legal Research) (Sinar Grafika 2018).

${ }^{30}$ Khususnya pada pasal 4 tentang kriteria lingkungan dan keberlanjutan. Lihat UUD NRI 1945, [Pasal 33 Ayat 4].
} 
yang layak. Maka dari itu, implementasi peraturan berbasis lingkungan pada area lebih khusus perlu diwujudkan. Keadaan ini khususnya dapat dilihat dalam pembentukan Undang-Undang Nomor 25 Tahun 2007 tentang Penanaman Modal yang merupakan dasar hukum kegiatan ber-investasi di Indonesia. ${ }^{31}$ Atas dasar tujuan untuk melaksanakan pembangunan ekonomi nasional yang berkelanjutan, maka dalam undang-undang tentang penanaman modal di Indonesia perlu untuk memerhatikan konsep pembangunan berkelanjutan khususnya pemenuhan atas keadaan lingkungan yang baik bagi masyarakat. Cerminan atas tujuan pemenuhan kebutuhan atas keadaan lingkungan tertera pada pasal 3 ayat 1 yang menyatakan bahwa: kegiatan investasi didasarkan pada beberapa asas yang dua diantaranya adalah asas berkelanjutan serta berwawasan lingkungan. ${ }^{32}$ Perwujudan aturan yang merhatikan kedua asas tersebut menunjukkan bahwa Indonesia telah memiliki peraturan yang menjamin kegiatan eco-investment, yang merupakan investasi berbasis lingkungan yang berkelanjutan. ${ }^{33}$ Keadaan ini dipermudah pula oleh berbagai peraturan yang digunakan untuk mengekang permodalan yang tidak ramah lingkungan serta mempermudah perizinan penanaman modal atas sumber daya yang dapat diperbarui. ${ }^{34}$ Kenyataan yang ada menunjukkan bahwa Indonesia secara hukum telah memerhatikan aspek lingkungan secara komprehensif.

Namun adanya tataran hukum tersebut tidak dapat menutup mata akan adanya fakta di lapangan, bahwa sebenarnya implementasi peraturan tersebut masih jarang terealisasi. Menurut salah satu penelitian yang dilakukan secara empiris, Indonesia masih memiliki insentif yang kecil terhadap keadaan lingkungan. ${ }^{35}$ Inti yang patut diperhatikan pada hasil telaah empiris ini adalah bahwa pemegang modal di Indonesia,

\footnotetext{
31 Jika dikaitkan dengan pengertian investasi sebagai kegiatan menanam maka penanaman modal dan investasi memiliki arti yang sama. Lihat Hwang and Cheng (n 11).

32 ibid. [Pasal 3 Ayat 1].

${ }_{33}$ Arti ini diperoleh dari sudut pandang dari ketentuan atas wawasan lingkungan. Lihat juga Ibid. [huruf g].

${ }^{34}$ Muhammad Insa Ansari and Adi Hermansyah, 'Dukungan Infrastruktur Hukum Dalam Pengembangan Green Investment Di Provinsi Aceh’ (2015) 17 Kanun Jurnal Ilmu Hukum 85.

${ }^{35}$ Hal tersebut dibuktikan dengan adanya kaitan positif antara investasi berbasis lingkungan atau eco-investment dengan keuntungan yang seharusnya diambil sebagai inisiatif diabaikan begitu saja. Lihat Rokhmawati and Gunardi (n 15).
} 
sebagai pihak yang berinvestasi terlihat mengabaikan isu emisi gas karbon atas kegiatan mereka dan malah berfokus pada pemaksimalan profit perusahaan. Keadaan ini menunjukkan bahwa peraturan yang ada tidak seimbang dengan implementasinya secara langsung pada kegiatan investasi di lapangan. Selain itu, sektor financial Indonesia, menurut data pada tahun 2015 menyatakan bahwa beberapa badan usaha masih di Indonesia masih tidak terlalu memandang isu tentang lingkungan secara baik. ${ }^{36}$ Keadaan ini salah satunya disebabkan oleh ketidakpastian gerakan politik negara. Ketidakpastian ini menimbulkan pespektif bahwa eco-investment memiliki resiko yang sangat tinggi. Namun, yang menarik adalah keinginan perusahaan terutama bank atas program investasi yang mendukung pembangunan berkelanjutan sangat signifikan. Hal tersebut menjelaskan bahwa perbaikan sistem politik terutama regulasi diperlukan untuk menjamin kesejahteraan bisnis.

Ketidakseimbangan regulasi dan implementasi yang terjadi disebabkan oleh berbagai faktor antara lain: harga atas karbon, subsidi atas tenaga fosil, biaya yang tinggi dan keuntungan yang dihasilkan dalam jangka waktu yang lama, resiko teknologi, serta ketertarikan pembiayaan. ${ }^{37}$ Adanya faktor-faktor tersebut menggambarkan bahwa kekhawatiran yang dirasakan oleh Indonesia termasuk sebagai salah satu diantaranya. ${ }^{38}$ Permasalahan tersebut dirasakan secara nyata oleh negara-negara berkembang yang masih ingin mendapatkan profit yang sebesar-besarnya demi membangun menuju negara yang maju. Paradigma yang berfokus pada profit tanpa adanya kesadaran terhadap kelestarian lingkungan

${ }^{36}$ Berdasarkan survey yang dilakukan, 49 dari 68 bank menyatakan bahwa eco-investment merupakan sektor yang menjanjikan dalam area bisnis (sisanya tidak menyerahkan maupun menyatakan tidak efektif) dan 69\% diantaranya merencanakan untuk memperluas jangkauan dari kegiatan ini. Dalam survey ini ada 4 bank yang benar-benar menyatakan secara jelas alasannya untuk tidak mempercayakan bisnis kepada gerakan eco-investment yang berkaitan dengan kepastian kesejahteraan kerja yang dipengaruhi oleh gerakan politik yang tidak menentu. Lihat data selengkapnya di Ulrich Volz, 'Towards a Sustainable Financial System in Indonesia' (2015).

37 Faktor-faktor ini didasarkan pada pernyataan dari World Bank pada tahun 2010. Lihat Marian Catalin Voica, Mirela Panait and Irina Radulescu, 'Green Investments - between Necessity, Fiscal Constraints and Profit' (2015) 22 Procedia Economics and Finance 73.

${ }^{38} \mathrm{Hal}$ ini terkait dengan pernyataan APEC pada tahun 2012 yang lalu. Lihat juga Rokhmawati and Gunardi (n 15). 
merupakan suatu bentuk pelanggaran dalam HAM terhadap lingkungan. ${ }^{39}$ Hal ini akan membahayakan kriteria HAM yang ada didalamnya seperti hak untuk hidup, kesehatan yang memadai, bekerja tanpa halangan, hak terbebas dari rasa takut, dan hak untuk hidup yang tercukupi; yang kesemuanya adalah bagian dari unsur kehormatan serta kebebasan setiap manusia. ${ }^{40}$ Selain itu, pernyataan lembaga keuangan, terutama bank di Indonesia menunjukkan bahwa kekhawatiran akan kesejahteraan finansial menjadi problematika dari gerakan eco-investment. Keadaan ini mencerminkan bahwa pemenuhan terhadap kebutuhan atas lingkungan yang baik perlu untuk memandang kesejahteraan pembisnis. Keadaan ini berkaitan dengan, pemenuhan hak atas pekerjaan yang layak yang juga merupakan salah satu bentuk perwujudan kepastian hukum sesuai dengan pasal ketentuan dalam dasar hukum tertinggi negara. ${ }^{41}$ Kondisi pentingnya kriteria lingkungan memerlukan perhatian yang khusus terhadap perwujudan kesejahteraan masyarakat. Munculnya dua kriteria pemenuhan HAM yang muncul menggambarkan sifat antara pengaruh keadaan lingkungan terhadap manusia sangatlah erat.

Pemenuhan hak atas lingkungan yang sehat memerlukan suatu regulasi yang kuat di Indonesia. Pernyataan tersebut didukung dengan survey yang menunjukkan bahwa keinginan masyarakat dalam melakukan kegiatan ecoinvestment dilatarbelakangi oleh kepatuhan terhadap peraturan perundangundangan. ${ }^{42}$ Keadaan ini menunjukkan bahwa peranan peraturan perundangundangan diperlukan untuk menggerakkan eco-investment di Indonesia sebagai investasi yang berorientasi lebih kepada penjaminan keadaan lingkungan yang

\footnotetext{
${ }^{39}$ Amedeo Postiglione, 'Human Rights and the Environment' (2010) 14 The International Journal of Human Rights 524.

${ }^{40}$ Pengaruh yang memunculkan urgensi atas pemenuhan hak-hak tersebut adalah fakta bahwa perubahan iklim yang menjadi semakin nyata dan penyesuaian hukum perlu untuk terus dilakukan. Lihat Ibid; dan juga Samvel Varvastian, 'The Human Right to a Clean and Healthy Environment in Climate Change Litigation' (2019).

${ }_{41}$ Unsur pekerjaan memerlukan suatu kelayakan yang selanjutnya merupakan salah satu bentuk HAM dalam konstitusi negara. Lihat UUD NRI 1945, [Pasal 27 Ayat 2 jo. Pasal 28E Ayat 1].

${ }^{42}$ Data penelitian didapatkan secara langsung dengan survey dan analisis terhadap lima macam variable yaitu: green investment, performa finansial, kepemilikan asing, profil industry, dan ukuran perusahaan. Lihat Anis Chariri and others, 'Does Green Investment Increase Financial Performance? Empirical Evidence from Indonesian Companies' (2018) 31 E3S Web of Conferences 5.
} 
baik di masa depan. Namun pada tahap implementasinya, penerapan peraturan tentang lingkungan masih menjadi permasalahan yang nyata pada sistem politik di Indonesia. Pernyataan tersebut didasarkan pada pelaksanaan sosialisasi hukum yang kurang efektif, kurangnya tenaga penegak hukum yang paham atas isu akan lingkungan, serta keengganan yang disebabkan oleh adat negara berkembang yang masih tidak dapat melepaskan kebiasaan lama yang sebenarnya berbahaya terhadap keadaan lingkungan. ${ }^{43}$ Permasalahan iklim hukum di Indonesia memerlukan negara untuk hadir dan memberikan suatu revolusi pola pemikiran masyarakat lewat pembentukan peraturan perundang-undangan yang pro terhadap pembangunan berkelanjutan; dimana kemudian dengan adanya pembentukan peraturan tersebut, negara perlu menyeimbangkan aspek normatif serta praktisnya.

\section{Hak Atas Kota Sebagai Perlindungan dan Pemenuhan HAM}

Kesejahteraan suatu negara di mulai dari bagaimana negara tersebut membangun desa dan kotanya. Kota merupakan wilayah dengan potensi kekayaan dan perkembangan, baik secara ekonomi, politik, budaya, dan lingkungan yang beragam. ${ }^{44}$ Bertukarnya hal baru dan inovasi dimulai dari perkotaan. Gaya dan cara hidup suatu masyarakat perkotaan menentukan ciri khas berhubungan antar sesama dalam suatu negara. Gemerlapnya perkotaan memancing orang berduyunduyun datang ke kota untuk mencari sesuap nasi dan pengharapan supaya hidupnya bisa sedikit naik kelas. Kecenderungan konsentrasi kekuasaan, pendapatan, dan aksesibilitas menjadi masalah utama di perkotaan. ${ }^{45}$ Permasalahan paling mendasar yang terjadi di perkotaan ialah kemiskinan yang menyebabkan kesenjangan

\footnotetext{
${ }^{43}$ Pendekatan yang dilakukan dalam mengidentifikasi masalah hukum ini dilakukan dengan berbasis pada hukum lingkungan. Lihat Fauzan Khairazi and others, 'Protection of the Right to a Good Environment and Healthy in Indonesia' (2017) 57 Journal of Law, Policy and Globalization 137.

${ }^{44}$ Sofie Viborg Jensen, 'Human Rights Cities: Local Governance or a Way of Life?' (Lund University 2018).

45 Somwrita Sarkar, 'Urban Scaling and the Geographic Concentration of Inequalities by City Size' (2018) 0 Environment and Planning B: Urban Analytics and City Science 2.
} 
sosial hingga kesenjangan ekonomi ${ }^{46}$ Peningkatan urbanisasi dari tahun ke tahun ditambah dengan privatisasi kesejahteraan publik mendukung dan berkontribusi dalam kerusakan lingkungan dan kerentanan bencana alam. ${ }^{47}$ Sistem pemerintahan perkotaan yang kurang memedulikan lingkungan serta regulasi yang minim turut serta menggerus kelestarian lingkungan. Ditambah, berbagai kepentingan politik dan oligarki semakin menggerogoti bahkan mengais sumber daya alam suatu kota, mengancam tingginya tingkat pencemaran dan kerusakan lingkungan.

Gagasan tentang bagaimana membangun kota yang inklusif, adil, dan mudah diakses muncul sebagai hak asasi manusia. Didasarkan pada Universal Declaration of Human Rights dan New Urban Agenda dikenal sebuah istilah 'hak di kota' serta 'hak atas kota'. ${ }^{48}$ Hal ini ditujukan untuk mewadahi ruang aspirasi yang menanamkan prinsip-prinsip hak asasi manusia. Ketika di tahun 2016 sebanyak 54,4\% populasi dunia tinggal di kota, berbagai pemukiman dan segala hal berkaitan dengan perekonomian tumbuh subur. ${ }^{49}$ Maka, menjadi sebuah urgensitas yang mendesak terpenuhinya hak di kota dan hak atas kota. Pemenuhan atas hak atas kota mewujudkan kota yang berkomitmen untuk melindungi, memenuhi, dan menerapkan hak asasi manusia. Bentuk konkret dari hal tersebut ialah ketika masyarakat menikmati serta berkontribusi dalam

46 Rory Hearne, 'Realising the "Right to the City": Developing a Human Rights Based Framework for Regeneration of Areas of Urban Disadvantage' (2013) 5 International Journal of Law in the Built Environment 172.

47 Salah satunya adalah transboundary haze pollution sebagai akibat dari penggunaan bahan bakar fossil yang berlebih demi pembangunan. Lihat Budi Winarno, 'The Value of International Regime and Global Environmental Crisis' (2017) 6 Jurnal Hubungan Internasional 81.

48 Barbara Oomen and Elif Durmus, 'Cities and Plural Understandings of Human Rights: Agents, Actors, Arenas’ (2019) 51 The Journal of Legal Pluralism and Unofficial Law 148.

49 Tina Kempin Reuter, 'Human Rights and the City: Including Marginalized Communities in Urban Development and Smart Cities' (2019) 18 Journal of Human Rights 2.and it is referred to as "right to the city" or "rights in the city." This article discusses how human rights relate to the city and its inhabitants, examines the meaning of the right to the city and human rights in the city in today's urban environment, and deliberates how to transform cities into spaces that reflect fundamental human rights principles. By looking at the situation of marginalized groups in cities, the article focuses on the questions of how to build inclusive, fair, and accessible cities and how to eliminate inequalities seen in urban communities. Because technology is often cited as one way to foster integration of marginalized communities, special attention will be given to the smart city and the opportunities and challenges presented by information and communication technologies (ICTs). 
kehidupan perkotaan dengan segala keuntungan dan pelayanan. ${ }^{50}$ Hak atas kota lebih dari sekedar kebebasan untuk mengakses sumber daya kota dan kesadarannya perlu ditanamkan di kalangan masyarakat kota di Indonesia. Masyarakat kota berhak ikut ambil bagian dalam penentuan ke arah mana pembangunan suatu kota akan dilakukan. Hal itu ditujukan sebagai wujud agar masyarakat kota nyaman tinggal di kotanya sebagai tempat tinggal sekaligus wadah dalam melangsungkan kehidupan sehari-hari.

Menurut Lefebvre, hak atas kota berarti hak untuk hidup dalam masyarakat. ${ }^{51}$ Dimana, setiap orang bebas untuk memenuhi keinginan mereka sendiri. Hal itu menjadi perlu, maka semua perlu dijaminnya hak atas kota. Hak atas kota terdiri atas dua hak utama yaitu, hak atas pemantasan kota dan partisipasi. ${ }^{52}$ Hak pemantasan kota dimaksudkan sebagai hak masyarakat untuk memanfaatkan ruang-ruang kota untuk melangsungkan kehidupan sehari-hari dan kegiatan lainnya. Lalu, hak partisipasi ialah hak peran serta masyarakat dalam proses pembuatan kebijakan dalam berbagai kebutuhan ruang-ruang kota. Kedua hak utama pada hak atas kota tersebut merupakan representasi seluruh masyarakat perkotaan, bukan justru dimiliki dan dikuasai oleh sekelompok orang tertentu. Maka, demi mengakomodasi itu dibuatlah Rencana Tata Ruang Wilayah (RTRW) yang mengatur dan menata kota. Pembuatan RTRW yang terdapat baik di pusat dan daerah menjadi patokan dalam perencanaan pembangunan. ${ }^{53}$ RTRW yang telah disepakati membutuhkan modal yang tidak sedikit, baik biaya dan proses yang panjang. Evaluasi pelaksanaan RTRW merupakan hal yang dapat menjadi bahan diskusi menarik. Hal itu dikarenakan implementasi pembangunan berdasarkan

\footnotetext{
${ }^{50}$ Hak atas kota dapat berbentuk pemenuhan hak warga atas pembangunan serta penikmatan kehidupan secara progresif. Lihat Muhammad Nurkhoiron, 'Mengembangkan Kota HAM Di Indonesia: Peluang Dan Tantangannya' (2017) 4 Jurnal Pemikiran Sosiologi 132.

${ }^{51}$ Mark Purcell, 'Possible Worlds: Henri Lefebvre and the Right to the City' (2014) 36 Journal of Urban Affairs 151.

52 Partisipasi akan sekaligus menimbulkan pemantasan atas kondisi keberadaan mereka sendiri. Lihat ibid.

53 Ruslan Wirosoedarmo, Jhohanes Bambang Rahadi Widiatmono and Yoni Widyoseno, 'Rencana Tata Ruang Wilayah (RTRW) Berdasarkan Daya Dukung Lingkungan Berbasis Kemampuan Lahan' (2014) 34 AGRITECH 464.
} 
RTRW menjadi masalah klasik diakibatkan lemahnya penegakan hukum. ${ }^{54}$

Ruang publik menjadi tempat yang berfungsi sebagai ruang berlangsungnya kegiatan masyarakat. ${ }^{55}$ Diperlukan sarana prasarana yang mapan dalam menunjang kebutuhan-kebutuhan masyarakat. Hal itu perlu untuk membantu manusia dalam mendapatkan kenyamanan, pemenuhan, dan perlindungan hak asasi manusianya. Ruang publik merupakan kawasan yang menonjol dalam pertumbuhannya. ${ }^{56}$ Beragam aktivitas dilakukan keseharian di kawasan tersebut, baik perekonomian, pendidikan, budaya, rekreasi, hingga pemerintahan. Kehidupan sosial yang tertata baik akan menunjang produktifitas dan peningkatan taraf hidup masyarakat itu sendiri. Setidaknya, ruang bagi publik memiliki 3 nilai yang perlu untuk dipenuhi, yakni responsif, demokratis, dan bermakna. ${ }^{57}$ Akan tetapi, terjadi privatisasi ruang publik. Hal ini menjadi masalah yang perlu diperbaiki pada setiap sistem perkotaan khususnya di Indonesia. ${ }^{58}$

Ruang-ruang publik yang terdapat di kota harus dimanfaatkan dengan memprioritaskan kepentingan sosial. ${ }^{59}$ Sebagaimana tujuan utamanya, kota harus melaksanakan fungsi sosial. Penjaminan atas penghuni dan sumber daya yang terdapat di kota sangatlah diperlukan. Pengembangan akses untuk mencapai keseimbangan antara pembangunan dan lingkungan hidup menjadi perlu. ${ }^{60} \mathrm{Hal}$ mendasar dalam menjaga kelangsungan manusia beraktivitas keseharian ialah

${ }^{54}$ Lemahnya penegakkan hukum yang ada diakibatkan oleh kurangnya keselarasan aturan hukum antara pemerintah daerah dan pemerintah pusat yang menghambat koordinasi wilayah. Lihat Ahmad Jazuli, 'Penegakan Hukum Penataan Ruang Dalam Rangka Mewujudkan Pembangunan Berkelanjutan’ (2017) 6 Jurnal RechtsVinding 274.

${ }_{55}$ Ruang tersebut digunakan sebagai media dalam membentuk identitas setiap orang. Lihat Nurkhoiron (n 50).[124].

${ }^{56}$ Hal tersebut didasari oleh sifat kota sebagai lingkungan bersama yang mengangkat derajat manusia secara individu maupun kolektif. Lihat pula ibid.[145].

${ }^{57}$ Edi Purwanto, 'Privatisasi Ruang Publik dari Civic Centre menjadi Central Business District (Belajar dari kasus Kawasan Simpang Lima Semarang)' (2014) 16 Jurnal Tataloka 156-157.

58 Eka Adhitya Hari Putra, 'Pengaruh Privatisasi Ruang Terbuka Publik Taman Tabanas Gombel Semarang terhadap Tingkat Kenyamanan Pengunjung’ (2014) 3 Teknik PWK (Perencanaan Wilayah Kota) 449.

59 Ana Sugranyes and Charlotte Mathivet, 'Cities for All: Articulating the Social-Urban Capacities' in Ana Sugranyes and Charlotte Mathivet (eds), Cities for All: Proposals and Experiences towards the Right to the City (2nd edn, Habitat International Coalition (HIC) 2011).[14].

${ }^{60}$ Joe Painter, 'Urban Citizenship and Rights to the City' (2005).[19]. 
perlindungan terhadap lingkungan hidup. Menjadi suatu hal yang mendesak untuk mengadopsi langkah-langkah menata perkotaan, pencegahan pencemaran, konservasi energi, hingga perlindungan daerah hijau. Pengembangan, perencanaan, regulasi, dan manajemen lingkungan perkotaan perlu untuk menjamin keseimbangan pembangunan perkotaan dan perlindungan alam.

\section{Kesimpulan}

Pembahasan yang telah dilakukan telah menarik suatu poin penting antara hubungan kebijakan investasi, HAM, dan perkotaan. Pemenuhan hak atas kota sebagai wujud perlindungan HAM membutuhkan tuntutan-tuntutan yang perlu diwujudkan. ${ }^{61}$ Urgensi penghidupan yang layak atas lingkungan yang bersih dan sehat merupakan poin penting. Pengembangan kebijakan eco-investment merupakan suatu gerakan yang dapat menjadi solusi pemenuhan tersebut. Tentu dengan adanya gerakan ini, permintaan akan kebersihan lingkungan, energi terbarukan, dan pencegahan pencemaran yang merupakan suatu keinginan bersama dimungkinkan untuk tercapai. ${ }^{62}$ Tuntutan untuk menjamin keseimbangan pembangunan kota dengan perlindungan alam atau lingkungan hidup tidaklah terpisah hanya fokus pada lingkungan saja. Tak hanya dalam visi misi kota yang diwujudkan dengan RTRW daerah, meski akomodasi perlindungan lingkungan telah tersedia, perlu adanya kajian yang mempertanyakan kelangsungannya. Keadaan ini menciptakan suatu kondisi pada perkembangan ilmu pengetahuan dan teknologi di masyarakat. Maka inovasi mengenai kelangsungan pemberdayaan lingkungan pada akhirnya memunculkan perspektif HAM atas pemenuhan keadaan lingkungan yang baik bagi setiap manusia. ${ }^{63}$ Dalam hal ini, yang patut menjadi perhatian ialah pergerakan arah pelestarian lingkungan lewat investasi berbasis lingkungan yang berkelanjutan.

\footnotetext{
${ }^{61}$ Reuter (n 49).[15].

62 Stephen Tully, 'The Human Right to Access Clean Energy' (2008) 3 Journal of Green Building 146.

${ }^{63}$ Rebecca M Bratspies, 'Reasoning Up to Human Rights: Environmental Rights as Customary International Law' in John Knox and Ramin Pejan (eds), The Human Right to a Healthy Environment (2018) [1].
} 
Pandangan dan cita-cita masa depan dipertaruhkan demi dunia yang lebih baik ke depannya. Komitmen atas upaya menjaga kelestarian dan kelangsungan lingkungan hidup yang baik harus ada dan menjadi fokus perhatian setiap pihak. ${ }^{64}$ Industrialisasi dan perkembangan perekonomian di era industri 4.0 saat ini memerlukan suatu gerakan yang berbasis lingkungan. Pembangunan ekonomi hampir terjadi di setiap negara termasuk Indonesia sebagai salah satu negara berkembang. ${ }^{65} \mathrm{Hal}$ itu menyebabkan ranah investasi atau penanaman modal menjadi minat negara-negara di dunia entah itu yang maju maupun berkembang. Perhatian pemerintah dalam memajukan pemenuhan atas lingkungan perlu dimajukan dan menjamin pemenuhan kebutuhan masyarakat atas pekerjaan sekaligus menjaga kualitas lingkungan. ${ }^{66}$ Dalam mewujudkan kota yang maju dibutuhkan infrastruktur yang tak mudah dan murah. Maka, menjawab kebutuhan itu proyek infrastruktur harus dibangun oleh korporasi internasional melalui sistem yang menekankan pemenuhan HAM khususnya atas pekerjaan dan lingkungan yang baik.

Pollution haven atau surga polusi merupakan akibat negatif atas investasi asing langsung. Hal ini terjadi dikarenakan lemahnya regulasi dalam perlindungan sumber daya alam dan lingkungan hidup atas efek perekonomian berupa industrialisasi. ${ }^{67}$ Komponen pengelolaan pencemaran jarang masuk atau hanya sebagian kecil pada tiap industri. Tentu hal ini berdampak pada kerusakan lingkungan akibat pencemaran. Sebagai langkah memperkecil biaya produksi industri atau perusahaan, mereka rela mengorbankan upaya pelestarian lingkungan. Fenomena ini perlu untuk dituntaskan, karena jika terbiarkan akan semakin menggerogoti keadaan lingkungan. Implementasi hukum menjadi hal yang wajib dilakukan, ditambah perkembangan dunia global yang pesat perkembangan hukum

${ }^{64}$ Boyle (n 23).

${ }^{65}$ Rokhmawati and Gunardi (n 15).

${ }^{66}$ Anis Chariri and others (n 42).

${ }^{67}$ Matthew A Cole, 'Trade, the Pollution Haven Hypothesis and the Environmental Kuznets Curve: Examining the Linkages’ (2004) 48 Ecological Economics 79. 
perlu mengimbangi situasi perkembangan teknologi yang ada. ${ }^{68}$ Tentu, kesadaran pengelolaan perekonomian haruslah ramah terhadap lingkungan. Kesadaran dan kepatuhan serta kepedulian itu akan mendorong terselenggarannya sistem perekonomian yang mapan dan banyak berdampak positif. Ditambah, upaya-upaya investasi berbasis lingkungan yang baru-baru ini didengungkan nampaknya akan menjawab kebutuhan dan tuntutan zaman yang semakin maju ${ }^{69}$ Adanya penerapan kebijakan hukum yang mendorong gerakan ini perlu dilakukan agar tercipta suatu harmonisasi yang selanjutnya dapat menciptakan suatu stabilitas pemenuhan HAM pada setiap manusia. ${ }^{70}$

\section{Daftar Bacaan}

\section{Buku}

Bratspies RM, 'Reasoning Up to Human Rights: Environmental Rights as Customary International Law' in John Knox and Ramin Pejan (eds), The Human Right to a Healthy Environment (2018).

Jensen SV, 'Human Rights Cities: Local Governance or a Way of Life?' (Lund University 2018).

Orsato RJ, Sustainability Strategies: When Does It Pay to Be Green? (Palgrave Mancmillan 2009).

Painter J, 'Urban Citizenship and Rights to the City' (2005).

Programme UNE, 'Delivering the Green Economy through Financial Policy' (2014).

Sugranyes A and Mathivet C, 'Cities for All: Articulating the Social-Urban

${ }^{68}$ Pandangan ini disampaikan pada acara Seminar Nasional "Membangun Konstruksi Hukum Ideal dalam Menyikapi Permasalahan Penataan Legislasi 4.0. di Indonesia” di Universtitas Jember pada tanggal 9 November 2019 oleh Dosen Tata Negara, Fakultas Hukum, Universitas Airlangga, Herlambang P Wiratraman, 'Bila Perkembangan Teknologi Lebih Cepat Daripada Hukum?: Mempertimbangkan Strategi Penataan Legislasi’ (2019).

${ }^{69}$ Pandangan ini disampaikan pada acara Seminar Nasional "Membangun Konstruksi Hukum Ideal dalam Menyikapi Permasalahan Penataan Legislasi 4.0. di Indonesia" di Universtitas Jember pada tanggal 9 November 2019 oleh Dosen Hukum Tata Negara, Fakultas Hukum, Universitas Jember, Bayu Dwi Anggono, 'Respon Legislasi Atas Era 4.0' (2019).

70 ibid. 
Capacities' in Ana Sugranyes and Charlotte Mathivet (eds), Cities for All: Proposals and Experiences towards the Right to the City (2nd edn, Habitat International Coalition (HIC) 2011).

Varvastian S, 'The Human Right to a Clean and Healthy Environment in Climate Change Litigation' (2019).

Volz U, ‘Towards a Sustainable Financial System in Indonesia' (2015).

Zaidun M, 'Paradigma Baru Kebijakan Hukum Investasi Indonesia Suatu Tantangan Dan Harapan’ (2008) 2.

\section{Jurnal}

Ansari MI and Hermansyah A, 'Dukungan Infrastruktur Hukum Dalam Pengembangan Green Investment Di Provinsi Aceh’ (2015) 17 Kanun Jurnal Ilmu Hukum 85.

Barry NP, 'The Philosophy of The Welfare State' (1990) 4 Critical Review: A Journal of Politics and Society 547.

Bose S and Springstell A, 'The Value and Current Limitations of ESG Data for the Security Selector' (2017) 8 Journal of Environmental Investing 66.

Boyle A, 'Human Rights and the Environment: Where Next?' (2012) 23 The European Journal of International Law 622.

Chariri A and others, 'Does Green Investment Increase Financial Performance? Empirical Evidence from Indonesian Companies' (2018) 31 E3S Web of Conferences 5.

Cole MA, 'Trade, the Pollution Haven Hypothesis and the Environmental Kuznets Curve: Examining the Linkages' (2004) 48 Ecological Economics 79.

Ganda F, Ngwakwe CC and Ambe CM, 'Profitability as a Factor That Spurs Corporate Green Investment Practices in Johannesburg Stock Exchange (Jse) Listed Firms' (2015) 13 Managing Global Transitions 233.

Hamlin A, 'The Idea of Welfare and the Welfare State' (2008) 8 Public Finance and Management 108.

Hearne R, 'Realising the "Right to the City": Developing a Human Rights Based Framework for Regeneration of Areas of Urban Disadvantage' (2013) 5 International Journal of Law in the Built Environment 172. 
Hwang M and Cheng JFL, 'Definition of "Investment" A Voice from the Eye of the Storm' (2011) 1 Asian Journal of International Law 100.

Jazuli A, 'Penegakan Hukum Penataan Ruang Dalam Rangka Mewujudkan Pembangunan Berkelanjutan' (2017) 6 Jurnal RechtsVinding 274.

Khairazi F and others, 'Protection of the Right to a Good Environment and Healthy in Indonesia' (2017) 57 Journal of Law, Policy and Globalization 137.

Melville LG, 'Economic Welfare’ (1939) 49 The Economic Journal 552.

Nurkhoiron M, 'Mengembangkan Kota HAM Di Indonesia: Peluang Dan Tantangannya' (2017) 4 Jurnal Pemikiran Sosiologi 132.

Oomen B and Durmus E, 'Cities and Plural Understandings of Human Rights: Agents, Actors, Arenas' (2019) 51 The Journal of Legal Pluralism and Unofficial Law 148.

Postiglione A, 'Human Rights and the Environment' (2010) 14 The International Journal of Human Rights 524.

Purcell M, 'Possible Worlds: Henri Lefebvre and the Right to the City' (2014) 36 Journal of Urban Affairs 151.

Purwanto E, 'Privatisasi Ruang Publik Dari Civic Centre Menjadi Central Business District (Belajar Dari Kasus Kawasan Simpang Lima Semarang)' (2014) 16 Jurnal Tataloka 156.

Putra EAH, 'Pengaruh Privatisasi Ruang Terbuka Publik Taman Tabanas Gombel Semarang Terhadap Tingkat Kenyamanan Pengunjung' (2014) 3 Teknik PWK (Perencanaan Wilayah Kota) 449.

Reuter TK, 'Human Rights and the City: Including Marginalized Communities in Urban Development and Smart Cities’ (2019) 18 Journal of Human Rights 2.

Rokhmawati A and Gunardi A, 'Is Going Green Good for Profit? Empirical Evidence from Listed Manufacturing Firms in Indonesia' (2017) 7 International Journal of Energy Economics and Policy 181.

Ruggie JG, 'Business and Human Rights: The Evolving International Agenda' (2011) 101 The American Journal of International Law 837.

Sarkar S, 'Urban Scaling and the Geographic Concentration of Inequalities by City Size' (2018) 0 Environment and Planning B: Urban Analytics and City Science 2. 
Sweify MF, 'Investment-Environment Disputes: Challenges and Proposals' (2016) 14 DePaul Business \& Commercial Law Journal 133.

Tully S, 'The Human Right to Access Clean Energy' (2008) 3 Journal of Green Building 146.

Voica MC, Panait M and Radulescu I, 'Green Investments - between Necessity, Fiscal Constraints and Profit' (2015) 22 Procedia Economics and Finance 73.

Winarno B, 'The Value of International Regime and Global Environmental Crisis' (2017) 6 Jurnal Hubungan Internasional 81.

Wirosoedarmo R, Widiatmono JBR and Widyoseno Y, 'Rencana Tata Ruang Wilayah (RTRW) Berdasarkan Daya Dukung Lingkungan Berbasis Kemampuan Lahan' (2014) 34 AGRITECH 464.

\section{Hearing}

Anggono BD, 'Respon Legislasi Atas Era 4.0' (2019). Disampaikan pada acara: Seminar Nasional "Membangun Konstruksi Hukum Ideal dalam Menyikapi Permasalahan Penataan Legislasi 4.0. di Indonesia" di Universtitas Jember (9 November 2019).

Wiratraman HP, 'Bila Perkembangan Teknologi Lebih Cepat Daripada Hukum?: Mempertimbangkan Strategi Penataan Legislasi' (2019). Disampaikan pada acara: Seminar Nasional "Membangun Konstruksi Hukum Ideal dalam Menyikapi Permasalahan Penataan Legislasi 4.0. di Indonesia" di Universtitas Jember (9 November 2019).

\section{Perundang-undangan}

Undang-Undang Dasar Negara Republik Indonesia Tahun 1945.

Undang-Undang Nomor 12 Tahun 2011 Tentang Pembentukan Peraturan PerundangUndangan (Lembaran Negara Republik Indonesia Tahun 2011 Nomor 82, Tambahan Lembaran Negara Republik Indonesia Nomor 5234).

Undang-Undang Nomor. 25 Tahun 2007 Tentang Penanaman Modal (Lembaran Negara Republik Indonesia Tahun 2007 Nomor 67, Tambahan Lembaran Negara Republik Indonesia Nomor 4724). 
--halaman ini sengaja dibiarkan kosong-- 